\title{
The level of knowledge about risk factors for cervical cancer and health-related behaviours of women from the area of the Świętokrzyskie Region
}

\section{Poziom wiedzy o czynnikach ryzyka wystapienia raka szyjki macicy a zachowania prozdrowotne kobiet z terenu województwa świętokrzyskiego}

\author{
Anna M. Lipińska1,2, Agnieszka Karnia¹, Anna Włoch², Magdalena M. Lipińska-Stańczak³, Anna M. Opuchlik2,4 \\ ${ }^{1}$ Rehabilitation of Hearing and Balance Organs, Institute of Physiotherapy, Faculty of Health Sciences, Jan Kochanowski University, \\ Kielce, Poland \\ Head of Institute: Prof. Stanisław Bień MD, PhD \\ ${ }^{2}$ Holycross Cancer Center, Kielce, Poland \\ Head of Centre: Stanisław Góźdź MD, PhD \\ ${ }^{3}$ Department of Pathobiomechanics, Institute of Physiotherapy, Faculty of Health Sciences, Jan Kochanowski University, Kielce, Poland \\ Head of Department: Prof. Andrzej Rydzewski MD, PhD \\ ${ }^{4}$ Institute of Physiotherapy, Faculty of Physical Education and Tourism, Holycross University, Kielce, Poland \\ Head of Department: Prof. Janusz Zdebski MD, PhD
}

Key words: cancer, risk factors, prevention, health-related behaviours.

Słowa kluczowe: rak, czynniki ryzyka, profilaktyka, zachowania zdrowotne.

\begin{abstract}
Introduction: In the world cervical cancer is the second most common malignant tumour among women, as well as the second most common cause of death. Most often this disease develops in women who are between 35 and 59 years old, i.e. at the time when many women raise children and are active professionally. There is a close correlation between the incidence of cervical cancer and lifestyle and the risk factors associated with it.

Aim of the research: Evaluation of the influence of knowledge about risk factors for cervical cancer on health-related behaviours of women from the area of the Świętokrzyskie Region.

Material and methods: The research material was obtained on the basis of a survey. The study was conducted among 108 randomly selected women in the age range 20 to 60 years.

Results: Based on the studies, a significant correlation between the women's health-related behaviours and their age, level of knowledge, and awareness of belonging to the group at risk of cervical cancer was found.

Conclusions: Among the respondents, older women showed more incorrect behaviours than younger women. It was also shown that the place of residence did not have an influence on health behaviour of the surveyed women. Respondents who participated in health education showed greater knowledge about the factors of cervical cancer than women not participating in the education. Women who were aware of belonging to the risk group for cervical cancer more often showed health-related behaviours.
\end{abstract}

\section{Streszczenie}

Wprowadzenie: Na świecie rak szyjki macicy jest drugim co do częstości występowania nowotworem złośliwym wśród kobiet, jak również przyczyną zgonów. Najczęściej występuje między 35. a 59. rokiem życia, czyli w momencie, kiedy wiele kobiet wychowuje dzieci i jest aktywnych zawodowo. Istnieje ścisła korelacja pomiędzy występowaniem raka szyjki macicy a stylem życia oraz związanymi z nim czynnikami ryzyka.

Cel pracy: Ocena wpływu wiedzy dotyczącej czynników ryzyka wystąpienia raka szyjki macicy na zachowania prozdrowotne kobiet z terenu województwa świętokrzyskiego.

Materiał i metodyka: Materiał badawczy uzyskano na podstawie ankiety. Badania przeprowadzono wśród 108 losowo wybranych kobiet $\mathrm{w}$ wieku 20-60 lat.

Wyniki: Stwierdzono istotną korelację między zachowaniami prozdrowotnymi kobiet a ich wiekiem, posiadaną przez nie wiedzą i świadomością przynależności do grupy ryzyka zachorowania na raka szyjki macicy.

Wnioski: Wśród ankietowanych starsze kobiety przejawiały więcej zachowań nieprawidłowych niż młodsze. Wykazano również, że miejsce zamieszkania nie wpływa na zachowanie zdrowotne badanych kobiet. Respondentki, które brały udział w edukacji zdrowotnej, mają większą wiedzę na temat czynników raka szyjki macicy od kobiet nieuczestniczących w edukacji. Kobiety świadome przynależności do grupy ryzyka wystąpienia raka szyjki macicy częściej przejawiają zachowania prozdrowotne. 


\section{Introduction}

Cervical cancer, globally, is the second most common cause of women's death due to oncological causes [1-4]. Worldwide, about 500,000 new cases are diagnosed annually and 275,000 women die of the disease. It is estimated that internationally, the number of women with cervical cancer is $1,400,000$. Almost $80 \%$ of cervical cancer cases are diagnosed in developing countries [2, 4]. In the European Union each year there are approximately 60,000 new cases of cervical cancer, and the number of diagnosed and treated women because of changes of cervical intraepithelial neoplasia (CIN) nature is probably twice as high [5].

Poland is the country with the highest incidence and mortality because of cervical cancer of all the countries in the European Union, and in terms of 5 -year survival it occupies the last place. Each year, about 3,500 Polish women find out that they have cervical cancer, and half of them die. Recently, serious concerns have been raised by a $16 \%$ increase in the incidence among young women under the age of 35 years. However, in women over 60 years old, the incidence of the disease is gradually decreasing. Most new cases occur in women between 45 and 59 years old [1, 3-5]. In 2007, cervical cancer was diagnosed in 4,057 women and 1,907 women died because of this cause. The incidence and mortality have remained constant for several years, and in 2007 they amounted to $20.6 / 100,000$ and $9.7 / 100,000[6,7]$.

Cervical cancer is a malignant tumour of known aetiology and risk factors. It was the first cancer for which a necessary etiological agent was diagnosed. The cause and effect relationship between HPV virus (Latin: Human Papillomavirus) and cervical cancer has been proven beyond a reasonable doubt. In 1996, the World Health Organisation recognised the oncogenic types of HPV 16 and 18 as carcinogenic to humans. As well as the HPV factor initiating the process of carcinogenesis, there are many other causes of cervical cancer (Table 1) [3, 4, 8-11].

The knowledge of the aetiology and risk factors for cervical cancer allows prevention and detection of the disease in the early stages of its development. The World Health Organisation has identified three types of prevention: primary, secondary, and tertiary. The most important of them is, of course, primary prevention, which is based on the elimination of causative factors, primarily through the implementation of vaccination against oncogenic type HPV and informing about risk factors for the disease and their "modification". Secondary prevention or cytological screening is used to recognise precancerous conditions or early stages of cancer, which allows for effective treatment. The next stage of preventive measures is tertiary prevention, which includes proper diagnosis and effective treatment, as well as follow-up examination and effective physiotherapy [4, 12-14].

\section{Aim of the research}

The main objective of the study is to assess the impact of knowledge about risk factors for cervical cancer on health-related behaviours of women from the area of the Holycross province. In order to accomplish the main objective of the work, the following research questions were posed: 1 . In what way does the women's age influence their health-related behaviours? 2 . Does the surveyed women's place of residence influence their health-related behaviours? 3. How does health education influence women's level of knowledge about the factors for cervical cancer? 4 . What health-related behaviours are manifested by women possessing sufficient knowledge about the factors for cervical cancer? and 5. In what way does the awareness of belonging to a group of high risk for cervical cancer affect the health-related behaviours of the examined women?

\section{Material and methods}

The research was conducted on a group of 108 women. Among the respondents, 46 (42.59\%) lived in the city and 62 (57.41) in rural areas in the Holycross province. In the age group of 20-30 years there were 29 (26.86\%) women, and between 31-40 years there

Table 1. The main and probable factors for cervical cancer [4]

\begin{tabular}{|c|c|}
\hline Main factors & Probable factors \\
\hline $\begin{array}{l}\text { - Infection with HPV } 16 \text { and } 18 \text { and other oncogenic types } \\
\text { - Age } \\
\text { - Early initiation of sexual activity } \\
\text { - A large number of sexual partners } \\
\text { - A large number of births } \\
\text { - Smoking } \\
\text { - Low socioeconomic status } \\
\text { - CIN } 2 \text { and } 3 \text { in an interview }\end{array}$ & $\begin{array}{l}\text { - Years of using hormonal contraceptives } \\
\text { - A diet low in antioxidants } \\
\text { - Frequent vaginitis caused by Chlamydia trachomatis, } \\
\text { Neisseria gonorrhoeae, and viruses: HSV-2, EBV, CMV }\end{array}$ \\
\hline
\end{tabular}


were $26(24.07 \%), 41-50$ years - 27 (25\%) women, and 51-60 years $26(24.07 \%)$ women. Most of the respondents had higher education 67 (62.04\%), a smaller group consisted of women with secondary education - $31(28.7 \%)$, while the smallest group of women had vocational education - 10 (9.26\%). Among the respondents there were 16 students (32.41\%), 59 working women (54.63\%), and 14 unemployed women $(12.96 \%)$. Sixteen $(14.81 \%)$ of the women rated their financial status at a very good level, $88(81.48 \%)$ at an average level, and $4(3.7 \%)$ of the examined women evaluated their status as insufficient (Table 2).

The research material was collected by the method of a diagnostic survey with an original questionnaire, which consisted of three parts. The first part included the respondents' demographic and social data such as age, place of residence, education, financial status, and current occupation. The second part of the questionnaire included questions assessing women's knowledge about risk factors for cervical cancer. The third part of the questionnaire concerned the women's health-related behaviours. Based on the available literature, the following health-related behaviours were recognised:

- initiation of sexual activity after the age of 18 ;

Table 2. The structure of the study group due to selected socio-demographic variables

\begin{tabular}{|ccc|}
\hline \multicolumn{1}{|c}{ Variables } & Number & Percentage \\
Age [years]: & & \\
$20-30$ & 29 & 26.86 \\
$31-40$ & 26 & 24.07 \\
$41-50$ & 26 & 25 \\
$51-60$ & & 24.07 \\
Place of residence: & 62 & 57.41 \\
Rural areas & 46 & 42.59 \\
City & & \\
Education: & 67 & 62.04 \\
Higher & 31 & 28.7 \\
Secondary & 10 & 9.26 \\
Vocational & & \\
Financial status: & 16 & 14.81 \\
Good & 88 & 81.48 \\
Average & 4 & 3.7 \\
Insufficient & & \\
Student & 35 & 32.41 \\
Working & 59 & 54.63 \\
Unemployed & 14 & 12.96 \\
\hline
\end{tabular}

- last visit to the gynaecologist not later than 3 years ago;

- having preventive examination no less frequently than every 3 years;

- regular cytological examination;

- non-use of oral contraceptives for more than 5 years;

- non-smoking;

- possession of knowledge about the causes of cervical cancer;

- participation in education about preventing cervical cancer;

- readiness for vaccination against HPV [4].

\section{Statistical analysis}

The obtained data was analysed statistically and descriptively with the use of Microsoft Excel and Gretl software. Percentages were calculated. Statistical analysis was presented by the $\chi^{2}$ test of independence. As a statistically significant value (IS), the level of significance less than or equal to $0.05(p \leq 0.05)$ was accepted. The lack of statistical significance was marked as the abbreviation NS. To assess the correlation between variables, a correlation coefficient $\left(r_{c}\right)$ was used.

\section{Results}

On the basis of the research analysis, statistical significance between health-related behaviours $(\mathrm{P})$ and the age of the women was found. In the studied group, proper health-related behaviours $(\mathrm{P})$ were observed in $39(40.74 \%)$ respondents, most of them 15 (51.72\%) among young women aged $20-30$ years. It was also observed that the frequency of health-related behaviours $(\mathrm{P})$ decreased with age, which is successively as follows: in the age group 31-40 years - 12 (46.15\%), 41-50 years - 7 (25.93\%), and 51-60 years - 5 (19.23\%). Analogically, the number of incorrect behaviours (NP) increased with age: in the age group 20-30 years - $14(48.27 \%)$ women manifested incorrect health-related behaviours (NP), 31-40 years - 14 (53.85\%) women, $41-50$ years old - 20 (74.07\%) women, 51-60 years - 69 (59.26\%) women (Table 3$)$.

The conducted research showed that there is no statistical correlation between the place of residence and health-related behaviours of the surveyed women. Among the respondents living in rural areas as many as $40(64.52 \%)$ manifested incorrect health-related behaviours (NP), and only 22 (35.48\%) reported correct ones $(\mathrm{P})$. Among women living in the city also most presented incorrect health-related behaviours (NP) - 29 (63.04\%), and correct behaviours (P) were presented by 17 (39.69\%) women (Table 4).

The research shows that the level of knowledge about risk factors for cervical cancer is statistically significant, dependent on women's participation in education on prevention. In the study group, 16 (57.14\%) women with sufficient knowledge about the factors 
Table 3. The influence of age on women's health-related behaviours

\begin{tabular}{|c|c|c|c|c|c|c|c|c|c|c|c|}
\hline \multirow{3}{*}{$\begin{array}{l}\text { Health-related } \\
\text { behaviours }\end{array}$} & \multicolumn{10}{|c|}{ Age of the respondents [years] } & \multirow{3}{*}{$\begin{array}{l}\text { Value } \\
\text { of } p\end{array}$} \\
\hline & \multicolumn{2}{|c|}{$20-30$} & \multicolumn{2}{|c|}{$31-40$} & \multicolumn{2}{|c|}{$41-50$} & \multicolumn{2}{|c|}{$51-60$} & \multicolumn{2}{|c|}{ Total } & \\
\hline & $n$ & $\%$ & $n$ & $\%$ & $n$ & $\%$ & $n$ & $\%$ & $n$ & $\%$ & \\
\hline$P$ & 15 & 51.72 & 12 & 46.15 & 7 & 25.93 & 5 & 19.23 & 39 & 40.74 & \\
\hline NP & 14 & 48.27 & 14 & 53.85 & 20 & 74.07 & 21 & 80.77 & 69 & 59.26 & 0.03 \\
\hline Total & 29 & 100 & 26 & 100 & 27 & 100 & 26 & 100 & 108 & 100 & \\
\hline
\end{tabular}

Table 4. Health-related behaviours that depend on the women's place of residence

\begin{tabular}{|c|c|c|c|c|c|c|c|}
\hline \multirow{3}{*}{$\begin{array}{l}\text { Health-related } \\
\text { behaviours }\end{array}$} & \multicolumn{6}{|c|}{ Place of residence } & \multirow{3}{*}{ Value of $p$} \\
\hline & \multicolumn{2}{|c|}{ Rural areas } & \multicolumn{2}{|c|}{ City } & \multicolumn{2}{|c|}{ Total } & \\
\hline & $n$ & $\%$ & $n$ & $\%$ & $n$ & $\%$ & \\
\hline$P$ & 22 & 35.48 & 17 & 39.96 & 39 & 36.11 & \\
\hline NP & 40 & 64.52 & 29 & 63.04 & 69 & 64.81 & 0.88 \\
\hline Total & 62 & 100 & 46 & 100 & 108 & 100 & \\
\hline
\end{tabular}

Table 5. The relationship between participation in an education program and women's knowledge about the factors for cervical cancer

\begin{tabular}{|c|c|c|c|c|c|c|c|}
\hline \multirow{3}{*}{$\begin{array}{l}\text { Participation } \\
\text { in education }\end{array}$} & \multicolumn{6}{|c|}{ The level of knowledge } & \multirow{3}{*}{ Value of $p$} \\
\hline & \multicolumn{2}{|c|}{ Sufficient } & \multicolumn{2}{|c|}{ Needs deepening } & \multicolumn{2}{|c|}{ Total } & \\
\hline & $n$ & $\%$ & $n$ & $\%$ & $n$ & $\%$ & \\
\hline Yes & 16 & 57.14 & 21 & 26.25 & 37 & 34.26 & \\
\hline No & 12 & 42.86 & 59 & 73.75 & 71 & 65.74 & 0.003 \\
\hline Total & 28 & 100 & 80 & 100 & 108 & 100 & \\
\hline
\end{tabular}

Table 6. The influence of women's level of knowledge on health-related behaviours

\begin{tabular}{|lccccccc|}
\hline $\begin{array}{l}\text { Health-related } \\
\text { behaviours }\end{array}$ & \multicolumn{9}{c}{ Level of knowledge } \\
\cline { 2 - 8 } & \multicolumn{2}{c}{ Sufficient } & \multicolumn{2}{c|}{ Needs deepening } & Total & Value of $p$ \\
\cline { 2 - 8 } & $n$ & $\%$ & $n$ & $\%$ & $n$ & $\%$ & \\
P & 16 & 57.14 & 23 & 28.75 & 39 & 36.11 & 0.007 \\
NP & 12 & 42.86 & 57 & 71.25 & 69 & 63.89 & \\
\hline Total & 28 & 100 & 80 & 100 & 108 & 100 & \\
\hline
\end{tabular}

for cervical cancer participated in the education; however, 12 (42.86\%) women, also with sufficient knowledge, did not take part in it. Among the respondents involved in the education, in 21 (26.25\%) women their knowledge needs deepening, while in 59 (73.75\%) women their knowledge needs deepening due to the lack of participation in the education (Table 5).

Analysis of the results showed statistical significance between the level of knowledge about cervical cancer and the health-related behaviours of the surveyed women. Among the respondents with a sufficient level of knowledge, health-related behaviours
(P) occurred more frequently - in 16 (57.14\%) women, and incorrect (NP) in $12(42.86 \%)$ women. In the group with the level of knowledge which needed deepening, the number of women with incorrect behaviours (NP) outnumbered - 57 (71.25\%); health-related behaviours were presented only by 23 (28.75\%) examined women (Table 6).

Based on the performed survey, it was found that there is a statistically significant relationship among the surveyed women between awareness of belonging to the group of risk of cervical cancer and the proper health behaviours presented by them (P) (Table 7). 
Table 7 Awareness of belonging to a group of women at high risk of cervical cancer and health-related behaviours

\begin{tabular}{|c|c|c|c|c|c|c|c|c|c|}
\hline \multirow{3}{*}{$\begin{array}{l}\text { Health-related } \\
\text { behaviours }\end{array}$} & \multicolumn{8}{|c|}{ Awareness of risk } & \multirow{3}{*}{$\begin{array}{l}\text { Value } \\
\text { of } p\end{array}$} \\
\hline & \multicolumn{2}{|c|}{ Yes } & \multicolumn{2}{|c|}{ No } & \multicolumn{2}{|c|}{ Don't know } & \multicolumn{2}{|c|}{ Total } & \\
\hline & $n$ & $\%$ & $n$ & $\%$ & $n$ & $\%$ & $n$ & $\%$ & \\
\hline$P$ & 6 & 50 & 21 & 45.65 & 12 & 24 & 39 & 36.11 & \\
\hline NP & 6 & 50 & 25 & 54.35 & 38 & 76 & 69 & 63.89 & 0.04 \\
\hline Total & 12 & 100 & 46 & 100 & 50 & 100 & 108 & 100 & \\
\hline
\end{tabular}

Among the women claiming belonging to a high-risk group there were $6(50 \%)$ who showed health-related behaviours (P) and 6 (50\%) who showed incorrect health-related behaviours (NP).

In the group of women aware that they do not belong to a risk group, 21 (45.65\%) showed health-related behaviours (P), and $25(54,35 \%)$ showed incorrect behaviours (NP).

Among the respondents unaware of belonging to a high-risk group there were 12 (24\%) who complied with the principles of health promotion $(\mathrm{P})$ and 38 (76\%) with incorrect health-related behaviours (NP).

\section{Discussion}

The prevention of malignant diseases is known as oncological prevention. Reducing the likelihood of the disease is possible thanks to the implementation of specific health behaviours [1, 15]. Analysing this problem, the researchers observed that cervical cancer is closely related to lifestyle. There is a correlation between negative behaviour in the past and the incidence of the disease in later life [16]. Cervical cancer is a malignant tumour of known aetiology and risk factors. This knowledge enables prevention and detection of the disease at an early stage of its development. Thus, widely understood cervical cancer prevention comes down primarily to the reduction of the incidence of new cases, limitation of factors predisposing to the disease, and efforts towards the early detection of neoplastic lesions [2, 8]. Health-related behaviours are the most important factors in preventing cervical cancer. Education about risk factors and possessed knowledge allow women to consciously choose behaviours that are considered to be correct and which, at the same time, prevent exposure to risk factors for cervical cancer and help to control their health condition. The range of activities of primary prevention includes making women and school-aged youths aware of the sphere of promoting healthy behaviours and avoiding risky behaviours to prevent the occurrence of sexually transmitted diseases, including human papilloma virus infections. Research carried out in the field of secondary prevention is called screening, which consists primarily of cytological screening, HPV testing, or a combination of both methods.
In developed countries the decline in mortality of women due to cervical cancer was obtained, among others, by raising women's health awareness [17, 18]. In turn, the lack of health education and poor access to preventive examinations has contributed to the high mortality in developing countries $[2,4,19$, 20]. Poland is the country with the highest ratio of incidence and mortality due to cervical cancer from among all European Union countries, and in terms of 5 -year survival it occupies the last place $[3,4]$. The authors' own research shows that most women (65.74\%) did not participate in health education. $74.07 \%$ of the examined women possessed insufficient knowledge about risk factors, and $46.3 \%$ did not possess knowledge about belonging to the group at increased risk for cervical cancer. Similar results were obtained by Mastelarz-Migas et al. [21], confirming that women's knowledge about cervical cancer is insufficient. However, it is worth emphasising, as confirmed in the authors' own study, that the respondents who participated in health education possessed greater knowledge about the risk factors for cervical cancer. Wozniak [22] conducted a survey of 100 randomly selected women on the program of early detection of breast cancer and cervical cancer, preventive examinations, and general knowledge about gynaecological cancers. Based on the research, she found that, regardless of age, education, and activity, the knowledge level of the surveyed women in this area is low. Other authors also confirmed the lack of association between the level of knowledge about risk factors for cervical cancer and the area of residence of the surveyed women [21]. The authors' own results also showed that there is no statistical correlation between the place of residence and health-related behaviours of the respondents.

However, the authors of the presented work observed a statistical correlation between the level of knowledge about cervical cancer and the health behaviours of the surveyed women. In the respondents with a sufficient level of knowledge, healthy behaviours were most frequent $-57.14 \%$. In the group of women in whom the level of knowledge was insufficient, incorrect health-related behaviours prevailed $-71.25 \%$

Analysis of the authors' own findings also shows that correct health behaviour depends on age: in the 
age group 20-30 years 15 (51.72\%) women declared health-related behaviours, 31-40 years - $12(46.15 \%)$ women, 41-50 years - 7 (25.93\%) women, and 51-60 years - $5(19.23 \%)$ women. Similarly, with age, the number of incorrect behaviours increases: in the age group 20-30 years 14 (48.27\%) women manifested health behaviours, 31-40 years old - 14 (53.85\%) women, 41-50 years - 20 (74. 07\%) women, and 51-60 years - 69 (59.26\%) women. On this basis it can be concluded that older women present more negative behaviours than younger women. Similar results were obtained by Jokel et al. [23], who investigated the changes in awareness and health-related behaviours of women for prevention of cervical cancer in the years 1976, 1986, 1990, and 1998. Evaluating their results, they stated that 'the lowest percentage of women declaring knowledge of cytological examinations and their role in the early detection of cervical cancer and less frequent prophylactic tests was among older women, with the poorest education and among the inhabitants of the village'.

The fact that young women aged 20-30 years and those with sufficient knowledge and awareness of belonging to the risk group more often show correct health behaviours, as well as that the place of residence did not affect the level of knowledge among the surveyed women, is positive. It can be assumed that health education brings the desired results, and the sense of danger of the disease exacts from women active participation in the prevention of cervical cancer and forms a sense of responsibility for their own health. However, the level of knowledge about risk factors for cervical cancer is insufficient and requires improvement. The results also show that the possessed knowledge about belonging to the group at high risk of cervical cancer does not encourage women to engage in proper health behaviours.

In summary, it can be concluded that the epidemiological situation in Poland requires the implementation of an active and universal prevention program. It is necessary to intensify education of women on the observance of personal and sexual hygiene and systematic preventive testing, because it is known that early diagnosis of cervical cancer depends on the level of women's knowledge about risk factors, as well as conscious behaviour in cancer prophylaxis.

\section{Conclusions}

On the basis of the conducted research a statistical significance between health-related behaviours and the age of the surveyed women was found. Among the respondents older women presented more negative behaviours than younger ones. The analysis of the research did not show a statistical correlation between proper health-related behaviours and the respondents' place of residence. In the examined group, women having sufficient knowledge about the risk factors for cervical cancer mostly presented proper health-related behaviours. The respondents taking part in health education showed more knowledge about the risk factors for cervical cancer than those who did not participate in the education. In the examined group, women aware of belonging to the group at high risk for cervical cancer more often showed health-related behaviours.

\section{References}

1. Podlińska M, Bernacka M, Gotlib J. Próba oceny wpływu wieku na poziom wiedzy na temat raka szyjki macicy wśród pacjentek hospitalizowanych w oddziale położniczo- ginekologicznym [Polish]. Pielęgniarstwo XXI wieku 2010; 30: 57-63.

2. Spaczyński M, Nowak-Markwitz E, Januszek-Michalecka L, Karowicz-Bilińska A. Profil socjalny kobiet a ich udział w Programie Profilaktyki i Wczesnego Wykrywania Raka Szyjki Macicy w Polsce [Polish]. Ginekol Pol 2009: 80: 833-8.

3. Spaczyński M, Kędzia W, Nowak-Markwitz E. Rak szyjki macicy. Profilaktyka, diagnostyka i leczenie [Polish]. PZEL, Warsaw 2009.

4. Miśta S, Kurowska M, Włodarczak A. Szczepionki przeciwko zakażeniom wirusem HPV dla nastolatek - przełom $\mathrm{w}$ profilaktyce raka szyjki macicy [Polish]. Klinika Nowa 2009; 16: 61-8.

5. Pokorna-Kałwak D, Pinkowska A, Muszyńska A. Szczepienia przeciw wirusowi HPV w praktyce lekarza rodzinnego [Polish]. Family Medicine Primary Care Review 2011; 13: 497-500.

6. Chybicka A. Zalecenia grupy ekspertów dotyczące pierwotnej profilaktyki raka szyjki macicy u dziewczat i młodych kobiet [Polish]. Pediatr Pol 2010; 85: 4-14.

7. Nowicki A, Borowa I, Maruszak M. zachowania zdrowotne kobiet w zakresie zapobiegania, wczesnego wykrywania stanów przedrakowych i raka szyjki macicy [Polish]. Ginekol Pol 2008; 79: 840-9.

8. Basta A, Pityński K. Rak szyjki macicy. In: Ginekologia onkologiczna [Polish]. Markowska J, Mądry R (eds.). Wydawnictwo MedPharm Polska, Wrocław 2008; 103-32.

9. Nowakowski A, Kotarski J. Czynniki ryzyka raka szyjki macicy i możliwości pierwotnej profilaktyki [Polish]. Przegl Epidemiol 2011; 65: 81-8.

10. Lewitowicz P, Horecka-Lewitowicz A, Adamczyk-Gruszka O. Knowledge of cervical cancer risk factors among students at the Jan Kochanowski University in Kielce. Studia Medyczne 2013; 29: 255-9.

11. Bąk B, Sikorski M, Wrześniewska M. Świadomość zdrowotna młodych kobiet zaszczepionych przeciwko wirusowi brodawczaka ludzkiego [Polish]. Studia Medyczne 2014; 30: 21-6.

12. Mariańczyk K, Steuden S. Oczekiwania oraz intencje zachowań zdrowotnych jako czynniki warunkujące wykonywanie profilaktycznej cytologii w grupie kobiet po 45 . roku życia [Polish]. Psychoonkologia 2011; 2: 55-64.

13. Słopiecka A. Zachowania kobiet w zakresie profilaktyki raka szyjki macicy [Polish]. Studia Medyczne 2013; 29: 287-92.

14. Bakalczuk G, Wdowiak A, Lewicka M. Ocena wykonywania profilaktycznych badań cytologicznych przez kobiety 
w okresie okołomenopauzalnym [Polish]. Przegl Menopauz 2012; 2: 129-34.

15. Syrjanen K, Erzen M, Syrjanen S. Cervical cancer control by organized screening. Issues to be considered in desiging a national programme control. Kolposkopia 2001; 1: 95-116.

16. Słopiecka A, Wiraszka G. Zachowania kobiet w zakresie profilaktyki chorób narządów płciowych [Polish]. Przegląd Uniwersytetu Rzeszowskiego i Narodowego Instytutu Leków w Warszawie, Rzeszów 2013; 1: 50-60.

17. Hawkins NA, Cooper CP, Saraiya M, et al. Why the Pap test? Awarensess and use of the Pap test among women in the United States. J Women Health 2011; 20: 511-7.

18. Hansen BT, Hukkelberg SS, Haldorsen T, et al Factors associated with non-attendance, opportunistic attendance and reminded attendance to cervical screening in an organized screening program: a cross-sectional study of 12,058 Norwegian women. BM Public Health 2011; 11: 264

19. Nwankwo RC, Aniebue UU, Aguwa EN, et al. Knowledge attitudes ana practices of cervical cancer screening among urban and rural Nigerian women: a call for education and mass screening. Eur J Cancer Care 2011; 20: 362-7.

20. Mupepi SC, Sampselle CM, Johnson TRB. Knowledge, attitudes and demographic factors influencing cervical cancer screening behavior of Zimbabwean women. J Women Health 2011; 20: 943-52.

21. Mastalerz-Migas A, Nowak A, Steciwko A. Wiedza i świadomość młodych kobiet w zakresie profilaktyki raka szyjki macicy [Polish]. Family Medicine Primary Care Review 2011; 13: 443-5.

22. Wożniak I. Wiedza o schorzeniach nowotworowych narządów kobiecych i postawy kobiet wobec badań profilaktycznych [Polish]. Problemy Pielęgniarstwa 2008; 16 136-43.

23. Jokel M, Bielska-Lasota M, Kraszewska E. Zmiany uświadomienia i zachowań zdrowotnych kobiet dotyczace profilaktyki raka szyjki macicy w latach 1976, 1986, 1990 1998. Przegl Epidemiol 2001; 55: 323-30.

\section{Address for correspondence:}

Anna Lipińska MD, PhD

Institute of Physiotherapy

Faculty of Health Sciences

Jan Kochanowski University

al. IX Wieków Kielc 19, 25-317 Kielce, Poland

E-mail: al.reha@wp.pl 